\title{
Solar Drying System Integrated with Phase Change Material (PCM)
}

\author{
S. P. Salve, A. M. Fulambarkar, P. D. Khune
}

\begin{abstract}
The post-harvest losses for agricultural products are around $30 \%-40 \%$ [1]. Drying is a one of the necessary processes for the preservation of agricultural products. Agricultural products require hot air of temperature above $40{ }^{\circ} \mathrm{C}$ for drying. Open sun drying takes more time for drying of products due to slower drying rates. Also, various factors hamper the quality of the dried product. Due to the moisture content in the products bacterial attack is possible. India being the tropical region has good solar radiation. It is advisable to use the solar dryer to avoid spoilage of quality of products [2]. In this work, the compact and portable forced convection solar dryer designed and developed for drying chilies with thermal energy storage. Solar dryer is having capacity of $15 \mathrm{~kg}$ and it consists of the flat plate collector based air heating system with thermal energy storage. Paraffin wax used as phase change material (PCM). The CFD simulations carried out for the solar dryer to study the temperature distribution over the surfaces of the flat plate collector and inside the drying chamber, velocity of air and phase change behavior of paraffin wax inside the trays. The energy stored in the paraffin wax and time required for charging and discharging of paraffin wax is found out. The time for which temperature in the drying chamber is maintained above $40{ }^{\circ} \mathrm{C}$ is also found out. Results of CFD simulations validated with the experimental results.
\end{abstract}

Keywords: Agricultural products, charging, discharging, drying, Phase change materials (PCM), Paraffin wax, solar dryer.

\section{INTRODUCTION}

Solar energy is one of the biggest sources of renewable energy. The United Nations Development Program has given in 2000 World Energy Assessment (WEA), that the annual potential of solar energy is 1,575-49,837 Exajoules (EJ).

This is many times larger than the total world energy consumption, which was 559.8 EJ in 2012 [3, 4]. Drying is the process of removing moisture from the product. Drying is the conventional method used for preservation of food and agricultural products like grains, vegetables and fruits. Solar dryer is a device that uses solar energy to dry substances [5]. Drying in Solar dryer uses the air collectors to collect the solar energy [6]. The purpose of solar drying is to minimize

Revised Manuscript Received on February 05, 2020.

* Correspondence Author

S. P. Salve*, Associate Professor, Mechanical Engineering Department, Pimpri Chinchwad Education Trust's Pimpri Chinchwad College of Engineering, Pune, India, Sanjay.salve@pccoepune.org

A. M. Fulambarkar, Principal, Pimpri Chinchwad Education Trust's Pimpri Chinchwad College of Engineering, Pune, India,

P. D. Khune, PG Scholar, ME Heat Power, Mechanical Engineering Department, Pimpri Chinchwad Education Trust's Pimpri Chinchwad College of Engineering, Pune, India, pradeeprajekhune170@gmail.com

(c) The Authors. Published by Blue Eyes Intelligence Engineering and Sciences Publication (BEIESP). This is an open access article under the CC BY-NC-ND license (http://creativecommons.org/licenses/by-nc-nd/4.0/) the moisture content of products to a level that can prevent the spoilage of agricultural products. Drying of products takes place by two processes. First is the heat transfer to the product using energy from the sun and mass transfer of moisture from the inner part of the product to its surface and second is from the surface to the surrounding air in contact with the product [7]. Traditionally the farmers are using the open drying technique, which uses solar radiation intensity, ambient temperature of air, humidity of ambient air and wind speed [8].

In the Solar Drying method the food and perishable items are directly placed on the ground floors, which can reach temperatures higher than the temperatures in open drying, and left there for a number of days to dry [9].

In solar air heaters, heat transfer from sun to absorber and absorber to fluid occurs. In order to enhance the performance of solar systems and solar dryers, usually modifications on solar air heaters are performed. Solar air heaters are special kind of heat exchangers that transform energy of solar radiation to internal energy of the transport medium [10]. The major component of any solar drying system is the solar air heater. Flat plate solar air heaters, though produce lower temperatures, have the advantage of being simpler in design, having lower maintenance and lower cost [11]. To obtain maximum amount of solar energy at minimum cost the flat plate solar air heaters with thermal storage have been developed. Flat plate solar air heaters are the type of solar air heaters which are extensively used in many applications such as residential, industrial and agricultural fields [12]. Solar air heaters, due to their simplicity are cheap and most widely used collection devices of solar energy, have great potential for low temperature applications, particularly for drying of agricultural products like chilies, However, the thermal efficiency of a solar air heater is comparatively very low because of the low values of the convective heat transfer coefficient between the absorber plate and the air, leading to high absorber plate temperature and high heat losses to the surroundings $[13,14]$. It has been discovered that the main thermal resistance to the heat transfer is due to the formation of a laminar sub-layer on the absorber plate heat-transferring surface. A flat plate solar air heater absorbs incident solar radiations and transforms them into useful heat for heating the collector fluid such as water and air. Solar air heaters, being very simple in design and cheap, are most widely used collection devices of solar energy [15]. Solar air heaters have several applications in space heating, seasoning of timber and crop drying [16].

Sohel Chaudhari et. al. has used CFD for the study of air flow, outlet temperature of air, temperature distribution over the flat plate collector, etc. Comparison of CFD and experimental provided [21]. 


\section{Solar Drying System Integrated with Phase Change Material (PCM)}

\section{PROBLEM STATEMENT}

Performance enhancement of Solar Dryer using phase change material (PCM).

\section{CFD METHODOLOGY}

\section{Methodology}

1. Design of Solar Dryer for drying capacity of $15 \mathrm{~kg}$.

2. CAD Model preparation and meshing.

3. Physics setup for problem and solution.

4. Post processing of CFD results and comparison with experimental results.

The 3D model consisting of the solar air heater and solar drying chamber is simulated in computational fluid dynamics. Following are the mesh and solver settings used for CFD simulation.

- Trimmed cell mesher

- Cell Count: 0.25 Million

- Three Dimensional

- Implicit unsteady simulation

- Gravity

- Turbulence Model: Realizable k-epsilon

- Wall Treatment: All Y+ wall treatment

- Solver: Segregated Solver

- Fluid: Air

- Gravity Model Used in the Simulation

- Cell Quality Remediation

- Solidification and melting model.

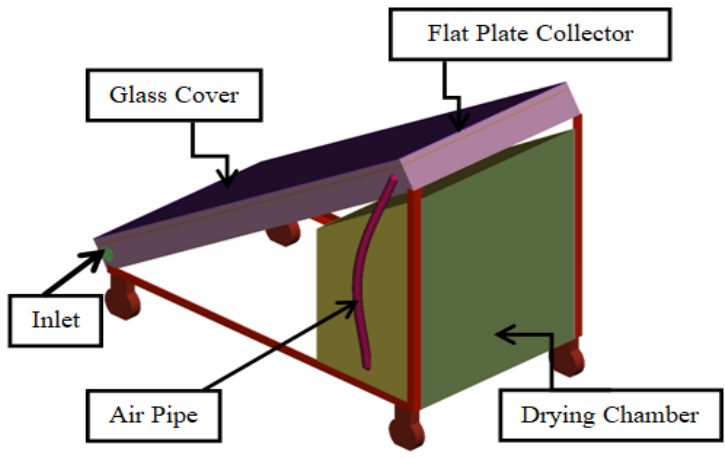

Fig. 1.CAD Model of Solar Drying System.

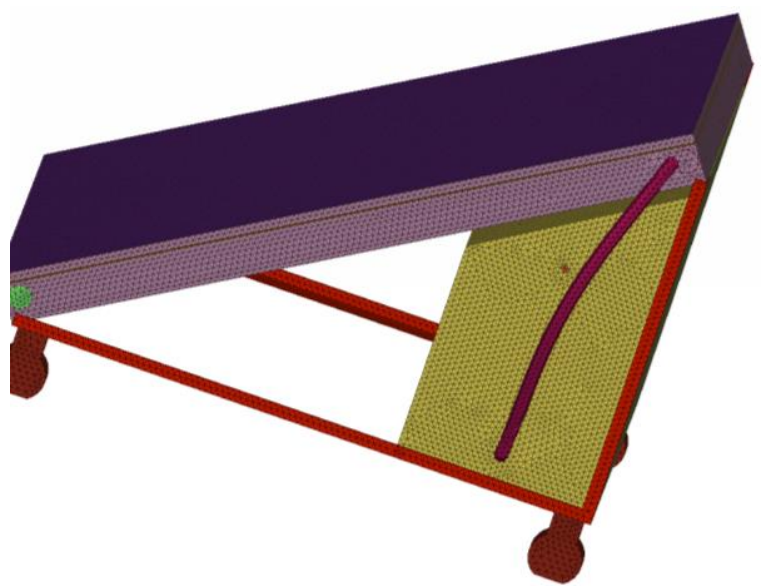

Fig. 2.Surface Mesh of Solar Dryer.
The flat plate collector specifications taken from the Indian Standards IS 12933 [2003]. The overall dimension for solar air heater is $2000 \mathrm{~mm} * 1000 \mathrm{~mm} * 100 \mathrm{~mm}$ with $50 \mathrm{~mm}$ thick Rockwool insulation from back side. Thermal conductivity of rock wool ranges from 0.0035 to 0.04 $\mathrm{W} / \mathrm{m}-\mathrm{K}$. Length and width of absorber plate are $1700 \mathrm{~mm}$ and $900 \mathrm{~mm}$ respectively. Aluminum cans of thickness 0.5 $\mathrm{mm}$ used for the manufacturing of air flow tubes of flat plate collector. The diameter of these aluminum can is $60 \mathrm{~mm}$. The spacing between absorber plate and bottom is $20 \mathrm{~mm}$. Air enters the flat plate air heater at atmospheric temperature. Two sheets of toughened glass ( $3 \mathrm{~mm}$ thick) were used to cover the heater in order to minimize the heat losses from the top of the air heater. The gap between the two glass covers equals $3 \mathrm{~mm}$. The heater was insulated from the sides using puff as an insulating material with thickness approximately $20 \mathrm{~mm}$. Puff insulation also used on the top and bottom header of the flat plate collector.

Properties of air, aluminum and glass which are used in the CFD simulation and while doing the calculations are given in the following tables. Mass flow rate of air entering into the flat plate collector is $0.01 \mathrm{~kg} / \mathrm{sec}$. Required mass flow rate of air calculated based upon the drying capacity of solar dryer which is $15 \mathrm{Kg}$.

Table- I: Properties of Air

\begin{tabular}{|l|l|}
\hline Property & Value \\
\hline Mass flow rate of Air & $0.01 \mathrm{~kg} / \mathrm{sec}$ \\
\hline Density & $1.18415 \mathrm{~kg} / \mathrm{m}^{3}$ \\
\hline Thermal Conductivity & $0.0260305 \mathrm{~W} / \mathrm{m}-\mathrm{K}$ \\
\hline Specific Heat & $1003.62 / \mathrm{kg}-\mathrm{K}$ \\
\hline
\end{tabular}

Table- II: Properties of Aluminum

\begin{tabular}{|l|l|}
\hline \multicolumn{1}{|c|}{ Property } & \multicolumn{1}{c|}{ Value } \\
\hline Density & $2719 \mathrm{~kg} / \mathrm{m}^{3}$ \\
\hline Thermal Conductivity & $202.4 \mathrm{~W} / \mathrm{m}-\mathrm{K}$ \\
\hline Specific Heat & $871 \mathrm{~J} / \mathrm{kg}-\mathrm{K}$ \\
\hline
\end{tabular}

Table- III: Properties of Glass

\begin{tabular}{|l|c|}
\hline \multicolumn{1}{|c|}{ Property } & \multicolumn{1}{c|}{ Value } \\
\hline Density & $2500 \mathrm{~kg} / \mathrm{m}^{3}$ \\
\hline Thermal Conductivity & $744.3 \mathrm{~W} / \mathrm{m}-\mathrm{K}$ \\
\hline Specific Heat & $670 \mathrm{~J} / \mathrm{kg}-\mathrm{K}$ \\
\hline
\end{tabular}

\section{RESULTS AND DISCUSSION}

Temperature distribution, pressure variation, and velocity fields are obtained by CFD simulation. Contours of temperature and pressure are given in Figures 3-5 below.

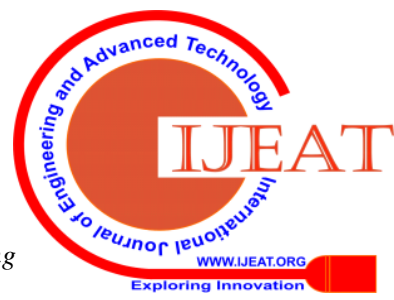


Temperature distribution over the top surface of the flat plate collector is shown in Fig. 3. Temperature is increasing from the inlet to the outlet of the Flat Plate Collector.

As the absorber plate absorbs the solar radiation over its length and stores the thermal energy it results in the temperature rise from the inlet to the outlet side of the flat plate collector. The temperature distribution shown in the Fig. 3 is obtained at 11:00 hours in the morning. This temperature goes on increasing till 14:00 hours as the solar radiation intensity increases.
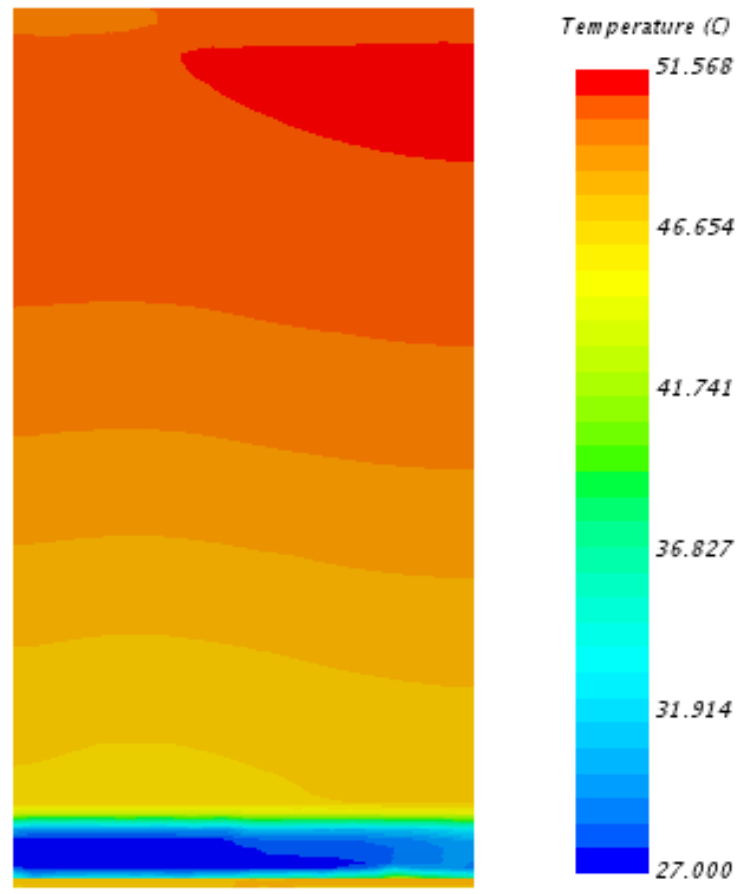

Fig. 3. Temperature Distribution over Flat Plate Collector
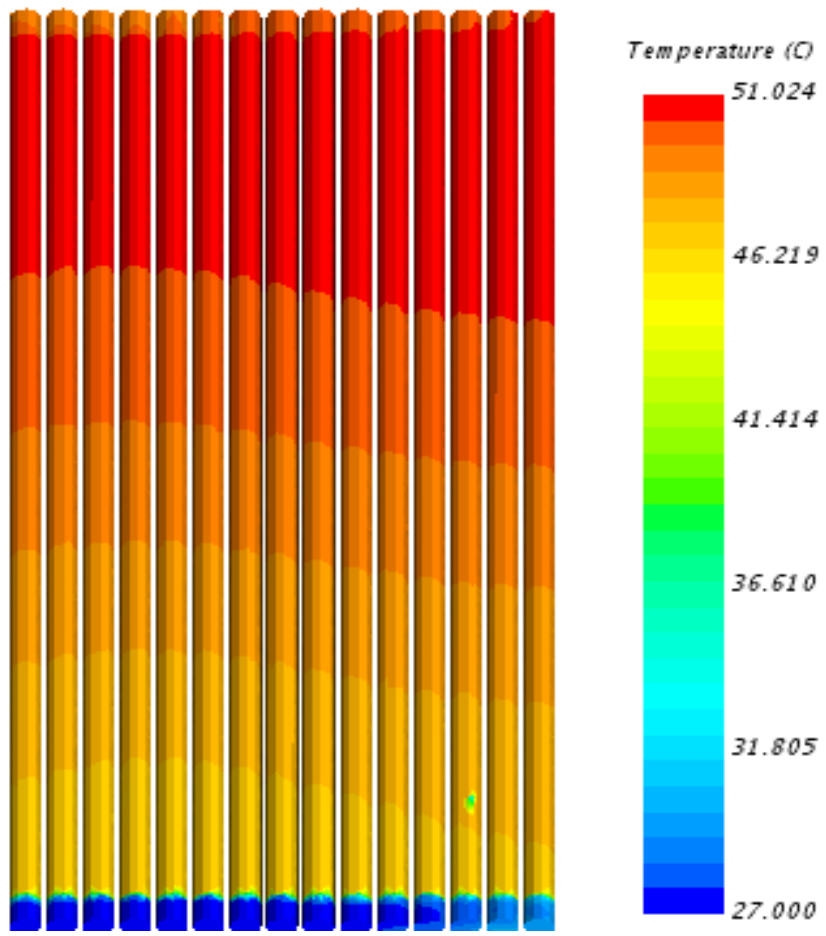

Fig. 4. Temperature Distribution over Flat Plate Collector Tubes
In the above Fig. 4 temperature distribution over the FPC tubes shown which is increasing from inlet to the outlet side. This temperature ranges from 27 to $52^{\circ} \mathrm{C}$ at the solar radiation intensity of $460 \mathrm{~W} / \mathrm{m}^{2}$ at $10: 00 \mathrm{Hrs}$. Pressure variation is shown in the Fig. 5 where pressure reduces from inlet to outlet side.

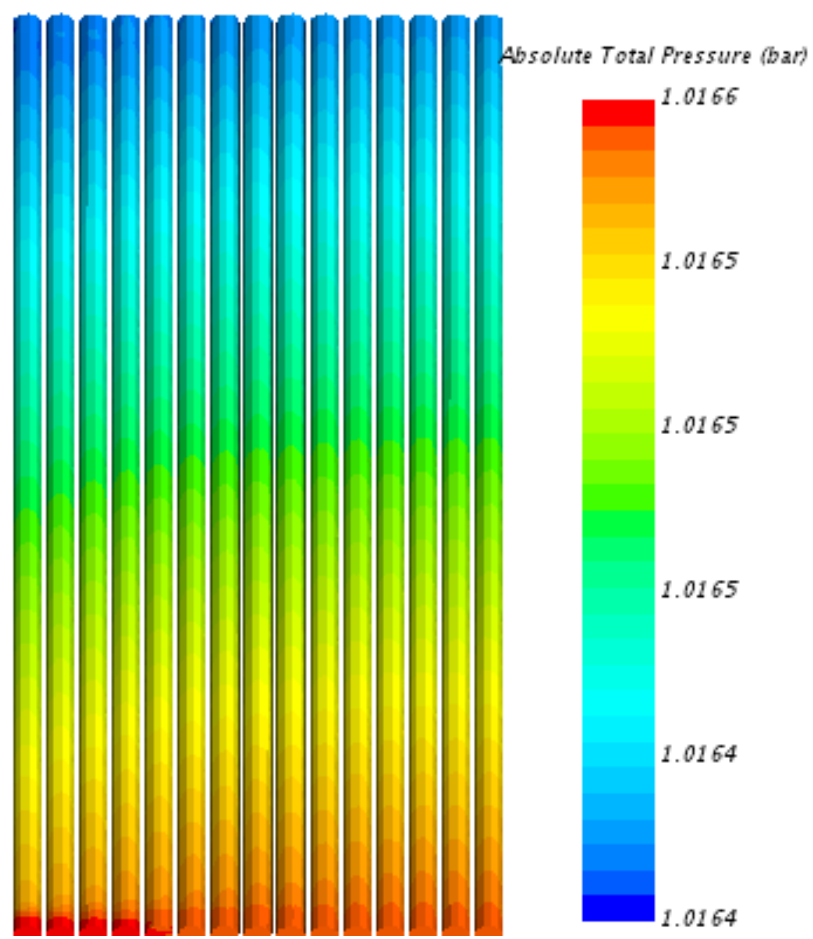

Fig. 5. Pressure Distribution over Flat Plate Collector Tubes

Temperatures of air in the drying chamber is shown in the figure 6 below which reduces from the lower side of the chamber to the upper side. This temperature image is at 13:00 Hrs. where maximum temperature of air reached is $70.279^{\circ} \mathrm{C}$.

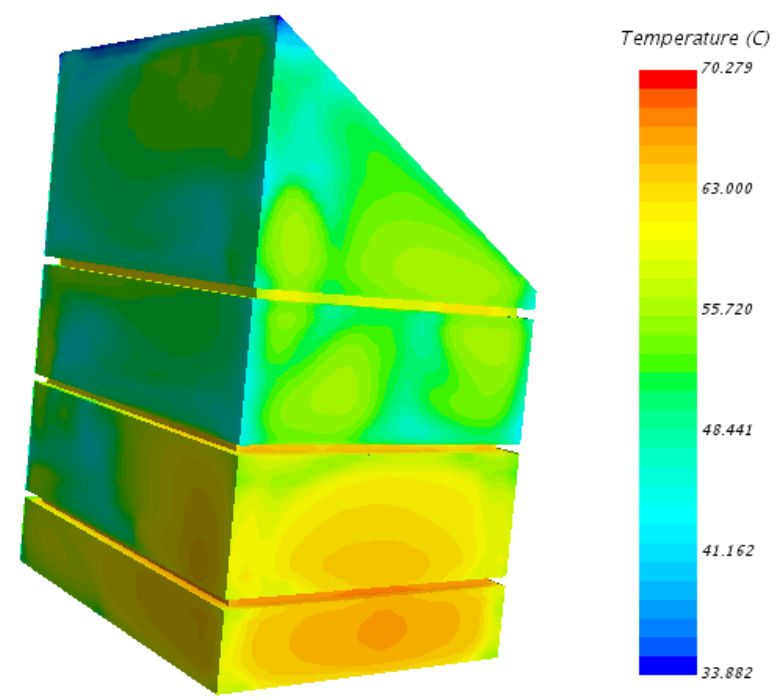

Fig. 6. Air Temperature Distribution in Drying Chamber

The maximum temperatures of air reached at 09:00, 10:00, 11:00 and 13:00 hours are 46.489, 49.887, 56.283 and 70.279 ${ }^{\circ} \mathrm{C}$ respectively.

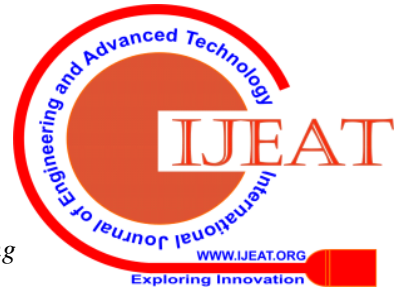




\section{Solar Drying System Integrated with Phase Change Material (PCM)}

The maximum and minimum temperature too of air is increasing as the radiation intensity increases.

It is observed that air is comparatively hotter in the lower compartment of the solar dryer and gets cooler as it reaches to the uppermost compartment.

The experimental and CFD drying chamber temperatures are given in the below graph. The temperature of the chamber predicted in CFD is around $5^{\circ} \mathrm{C}$ higher than the experimental temperature. This might be due to the heat losses from the top, bottom and sides of the flat plate collector and the pipe connecting outlet of flat plate collector to the inlet of drying chamber. Temperature of the drying chamber drops very slightly after 19:00hrs which can be seen in the plot.

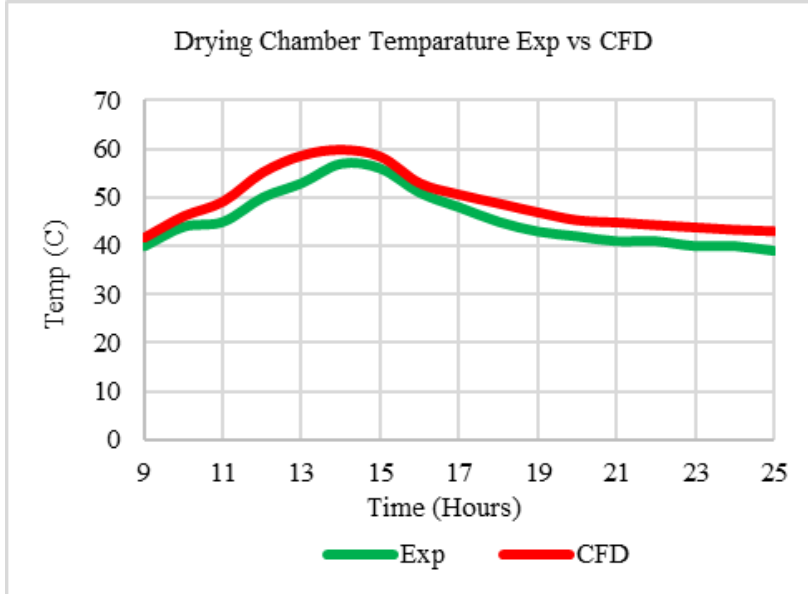

Fig. 7. Drying Chamber Temperature Exp and CFD

The temperatures of PCM at different times is given in the following image. The temperatures shown in the image is at 10:30 hours. As the air is entering to the drying chamber from the lower side temperature of the lower tray increases first and then subsequently increases the temperatures of the trays above it. This temperature distribution is visible in the below Fig. 8. This figure is representation of the charging process of phase change material.

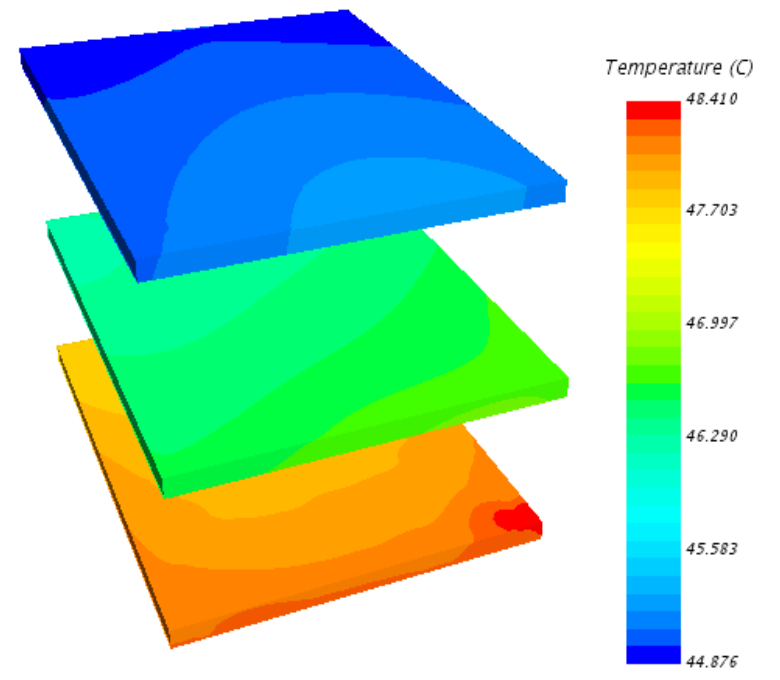

Fig. 8. Temperature of Phase Change Material

The volume fractions of solid and liquid phases are shown in the following image. This image shows the charging process of phase change material. It melts over the temperature range from $44^{\circ} \mathrm{C}$ to $55^{\circ} \mathrm{C}$. The image shows the volume fraction of liquid and solid at 11:00 Hrs.

Solid Volume Fraction of Phase 1
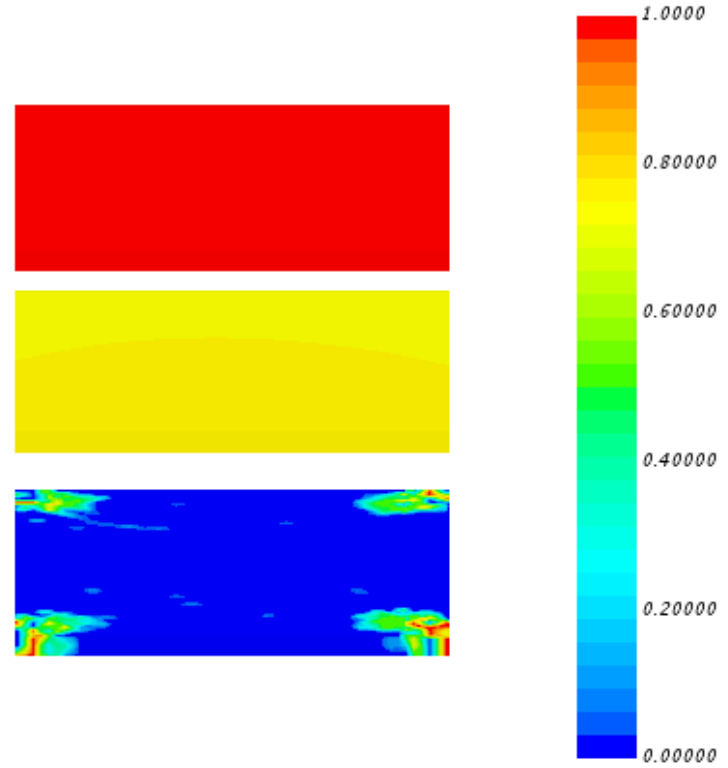

Fig. 9. PCM volume fraction of liquid and solid

The comparison of drying chamber temperature with and without the use of PCM is done with the help of CFD simulations. The temperatures in the drying chamber are higher during the sunshine hours and lower after sunshine hours when PCM is not used in the trays of drying chamber. When PCM used in the trays inside the drying chamber the energy is used by PCM for its charging during the sunshine hours resulting in the comparatively lower chamber temperatures during then sunshine hours. This energy is given away by the PCM after the sunshine hours maintaining the drying chamber temperature higher than the outside ambient temperature. It has been observed that the temperature of drying chamber maintained above $40^{\circ} \mathrm{C}$ even after sunshine hours due the discharging of paraffin wax inside the trays in drying chamber. The plot showing the comparison of drying chamber air temperatures with and without phase change materials is below.

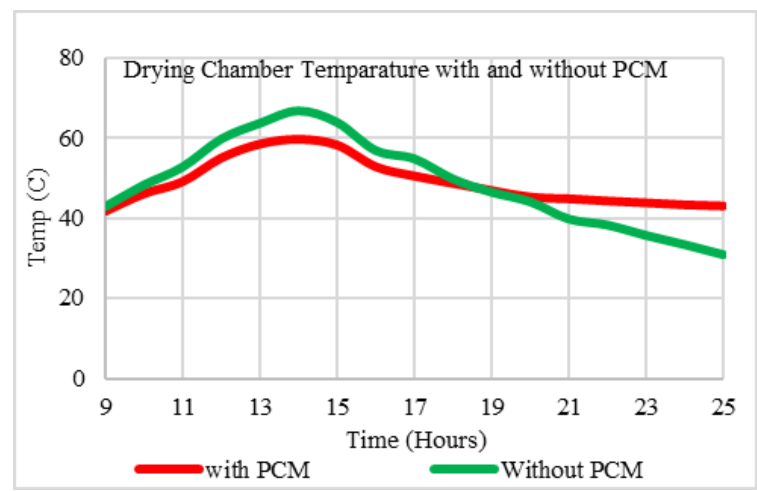

Fig. 10. Drying Chamber Temperature with and without PCM 
The energy content at different times during the charging and discharging of paraffin wax are plotted in the graph below.

It can be seen that both charging and discharging process takes around 8 hours each. The sensible heat is added to the PCM for initial 4 hours followed by the latent heat for next 2.5 hours and then again sensible heat for next 1.5 hours during the charging process. The same phenomenon in the reverse order takes place during the discharging. The energy stored during the charging process is around $1000 \mathrm{~kJ}$ as evident from the below Fig. 11.

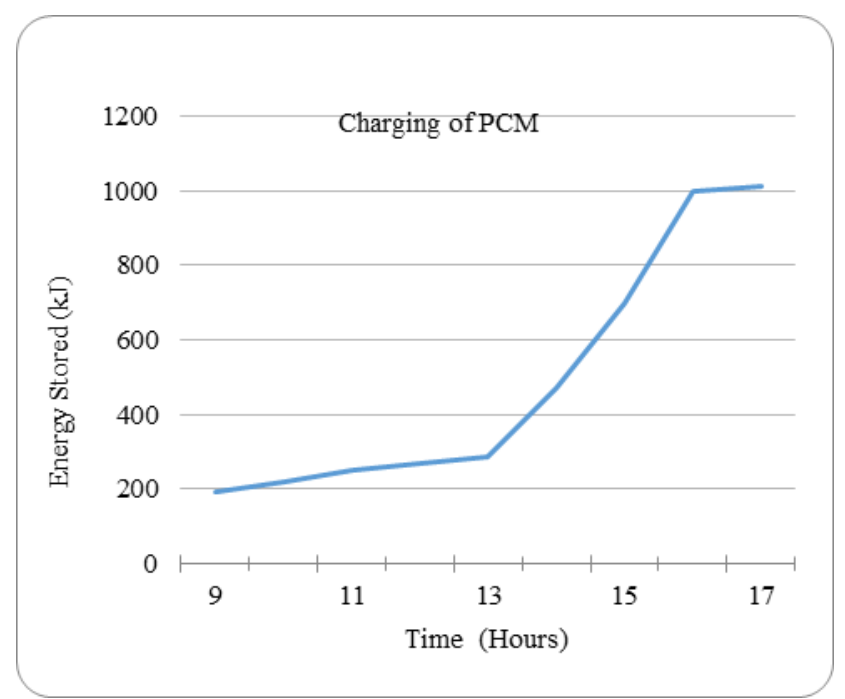

Fig. 11. Charging of PCM

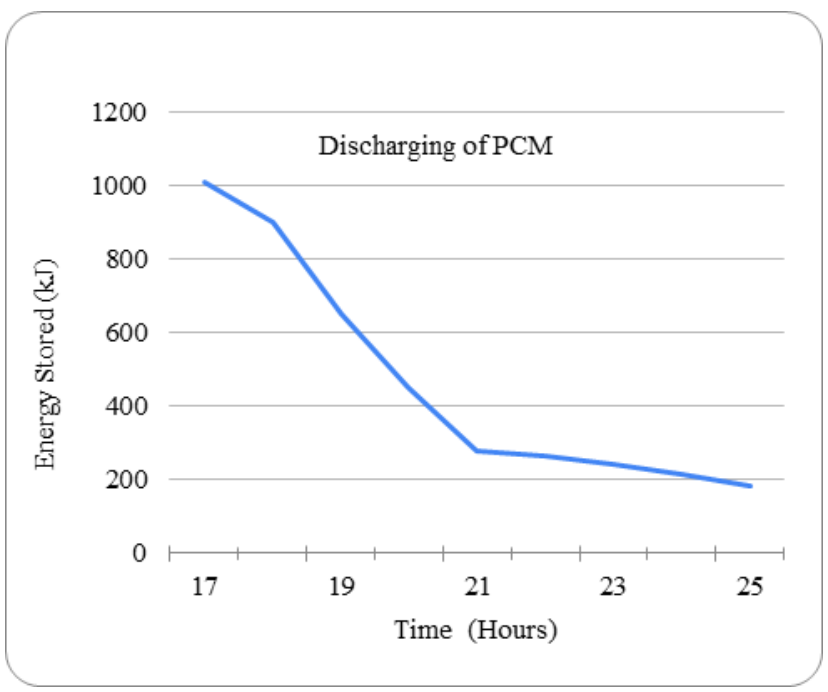

Fig. 12. Discharging of PCM

\section{CONCLUSION}

- Through comparison of Experimental and CFD temperatures of drying cabinet it is observed that there is difference of around $5{ }^{\circ} \mathrm{C}$ between the temperatures obtained in experimental measurements and CFD calculations.

- It can be seen from the temperature plots of drying cabinet that from 09:00 Hrs. to 25:00 Hrs. the temperature of air measured above $40{ }^{\circ} \mathrm{C}$ with PCM case, as compared to 09:00 Hrs. to 18:00 Hrs. without PCM case.

- The required drying temperature (above $40 \quad{ }^{\circ} \mathrm{C}$ ) maintained in the dryer for 7 more hours due to the use of PCM.

- At the time of 13 Hrs. to 15 Hrs. maximum temperature of outlet air obtained in CFD. This is validated with the experimental temperature during this time span.

- The temperature and flow distribution observed in the drying cabinet is not uniform with the higher temperature and velocity in the lower compartment of the Solar Dryer. By making the more space for air flow from one to the other compartment the uniformity of velocities and temperatures can be improved.

- Lower PCM tray charges first as the air flow and temp in the lower compartment is higher.

- For charging and discharging of PCM it takes around 8 hours' time.

- At 16:00 Hrs. paraffin wax completely converts into liquid phase.

\section{REFRENCES}

1. "Solar drying of agricultural products: A review, pp 37-43", A. A. El-sebaii, S.M Shalaby (2012).. Renewable and Sustainable Energy Reviews, ELSEVIER.

2. "Comparitive study of open sun drying and solar cabinet drying techniques for drying of green chillies", Ashish Kumar, Ajeet Rai, International Journal of Production Technology and Management, Volume 1, Issue 1, Jan-Jun 2016.

3. "2014 Key World Energy Statistics" (PDF). iea.org. IEA. 2014. pp. 6, 24, 28. Archived (PDF) from the original on 5 May 2015.

4. "Energy and challenge of sustainability" (PDF). United Nations Development Program and World Energy Council. September 2000. Retrieved 17 January 2017.

5. A.Hachemi, B.Abed and A.Asnoun, "Theoretical and experimental study of solar dryer", Elsevier Science Ltd., Volume13, Issue4, April 1998, Pages 439-451.

6. Margarita Castillo Tellez, Isaac Pilatowsky Figueroa, Beatriz Castillo Tellez, Erick C. Lopez Vidana, Anabel Lopez Ortiz, "Solar drying of Stevia (Rebaudiana Bertoni) leaves using direct and indirect technologies", Elsevier, Solar Energy 159 (2018) 898-907

7. Syed Mohammed Shamiq, P Sudhakar and M Cheralathan,"Experimental study of a solar dryer with different flow patterns of air in the drying chamber", 2nd International conference on Advances in Mechanical Engineering (ICAME 2018), IOP Conf. Series: Materials Science and Engineering 402 (2018) 012014 doi:10.1088/1757-899X/402/1/012014

8. Lokesh R. Dhumne, Vipin H. Bipte, Prof. Y. M. Jibhkate, "Solar Dryers For Drying Agricultural Products", IJOER, Vol.3., S2, 2015, ISSN: 2321-7758.

9. Shuilian Li, Hui Wang, Xiangrui Meng, Xinli Wei, Comparative study on the performance of a new solar air collector with different surface shapes, Applied Thermal Engineering, S1359-4311(16)33866-2.

10. Amit Sharma, Noor Danish Ahrar Mundari, "A Review on Solar Air Heating and Drying Techniques", IJETMAS, Management and Applied Sciences, www.ijetmas.com June 2017, Volume 5, Issue 6, ISSN 2349-4476.

11. B. K. Bala1 and Nipa Debnath, "Solar Drying Technology: Potentials and Developments", Journal of Fundamentals of Renewable Energy and Applications, Vol. 2 (2012), Article ID R120302, 6 pages,doi:10.4303/jfrea/R120302.

12. I. S. Jacobs and C. P. Bean, "Fine particles, thin films and exchange anisotropy," in Magnetism, vol. III, G. T. Rado and H. Suhl, Eds. New York: Academic, 1963, pp. 271-350.

13. A.A. El-Sebaii , S. Aboul-Enein , M.R.I. Ramadan , S.M. Shalaby, B.M. Moharram "Investigation of thermal performance of-double pass-flat and v-corrugated plate solar air heaters", Science direct, 28 November 2010.

14. A.A. El-Sebaii , S. Aboul-Enein , M.R.I. Ramadan , S.M. Shalaby, B.M. Moharram "Thermal performance investigation of double pass-finned plate solar air heater". Science direct, 18 December 2010

15. A.E. Kabeel, Mofreh H. Hamed, Z.M. Omara, A.W. Kandeal, "Solar air heaters: Design configurations, improvement methods and applications - A detailed review", Elsevier, Renewable and Sustainable Energy Reviews 70 (2017) 1189-1206. 
16. N.K. Bansal, "Solar Air Heater Applications in India", Elsevier Science Ltd, Renewable Energy 16 (1999) 618423.

17. H.D.Ammari." A mathematical model of thermal performance of a solar air heater with slats", science direct, November-2002.

18. Dr. A. A. Pawar, Prof. P.W. Ingel, Prof. B. D. Deshmukh, Prof. K. C. Bhosale,"CFD Analysis of solar flat plate collector', Innalternational journal of emerging technology and advanced engineering, volume 3, April 2013.

19. Dr. J. L. Bhagoria "CFD Analysis of Square ribs on the Absorber Plate of Solar Air" 2nd International Conference on Mechanical, Electronics and Mechatronics Engineering, 17, june-2013.

20. Anil Singh Yadav, J.L.Bhagoria "A CFD Analysis of a Solar Air Heater Having Triangular Rib Roughness on the Absorber Plate"International Conference on Global Scenario in Environment and Energy, 16, march 2013.

21. Sohel Chaudhari et. al. "CFD Analysis of Solar Air Heater", Sohel Chaudhari et al Int. Journal of Engineering Research and Applications, ISSN : 2248-9622, Vol. 4, Issue 6( Version 6), June 2014, pp.47-50.

22. Chii-DongHo, HsuanChang, Rei-ChiWang, Chun-ShengLin "Performance improvement of a double-pass solar air heater with fins and baffles under recycling operation, Elsevier Science Ltd., Applied Energy, Volume 100, December 2012, Pages 155-163.

\section{AUTHORS PROFILE}

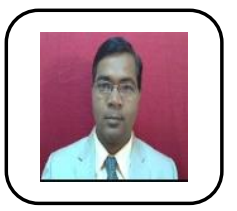

Mr. S. P. Salve, Associate Professor, Mechanical Engineering Department, Pimpri Chinchwad Education Trust's Pimpri Chinchwad College of Engineering, Pune. He has completed B. E. Mechanical and M. Tech. in Heat Power Engineering from College of Engineering, Pune. Pursing Ph. D. from Savitribai Phule Pune University under the guidance of Dr. A. M. Fulambarkar on Solar Drying System. He has a teaching experience of over 16 years. He stood first in Maharashtra in Avishkar- 2019, a competition for Ph. D. scholars to present their work. His area of specialization is thermal engineering, energy engineering and solar drying systems. He is author and co- author of many research and review papers in different international journals.

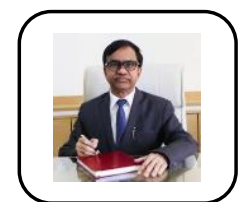

Dr. A. M. Fulambarkar, Currently working as Principal, Pimpri Chinchwad College of Engineering, Pune. Formerly associated with with Bapurao Deshmukh College of Engineering, Sewagram, Dist. Wardha as Professor and Head, Department of Mechanical Engineering and officiating Principal. He carries academic and administrative experience of more than 30 years. Having passed Bachelor of Engineering in Mechanical Engineering Discipline in 1982 from Govt. College of Engineering Amaravati (MS), he prosecuted post-graduation in Production Engineering from Visvesaraya National Institute of Technology, Nagpur (MS) in 1988. Dr. A. M. Fulambarkar has been awarded Ph.D. in Mechanical Engineering by Nagpur University, Nagpur. He has published and presented research papers in various national and international conferences. He was chairman, Board of Studies of Mechanical Engineering in Nagpur University from 2000 to 2005. He is a Rotarian and associated with many Social Organizations.

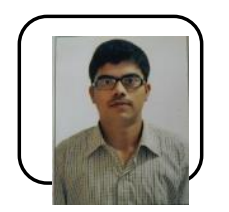

Mr. P. D. Khune, PG Scholar, ME Heat Power, Mechanical Engineering Department, Pimpri Chinchwad Education Trust's Pimpri Chinchwad College of Engineering, Pune. 